\title{
AGING AND DEGENERATION OF THE INTERVERTEBRAL DISC: REVIEW OF BASIC SCIENCE
}

\author{
ENVELHECIMENTO E DEGENERAÇÃO DO DISCO INTERVERTEBRAL: REVISÃO DA CIÊNCIA BÁSICA

\section{EL ENVEJECIMIENTO Y LA DEGENERACIÓN DEL DISCO INTERVERTEBRAL: REVISIÓN DE LA} \\ CIENCIA BÁSICA
}

Josemberg da Silva Baptista ${ }^{1}$, Ricardo Bragança de Vasconcellos Fontes² ${ }^{2}$ Edson Aparecido Liberti ${ }^{3}$

\begin{abstract}
Currently there is a growing interest in the study of intervertebral discs due to loss of manpower brought to society by low back and neck pains. These papers seek to delineate the difference between normal aging and disc degeneration, trying to understand what factor would be determining for the second condition. Thus, the morphology field was expanded and knowledge on the structure of intervertebral discs currently uses the research field of cell and molecular biology, and genetics. The results indicate that regardless of age or condition, the intervertebral disc undergoes long and extensive remodeling of its constituents, which are influenced by several factors: environmental, soluble, cell growth and extracellular matrix. In this literature review we describe the biological characteristics of the cervical and lumbar intervertebral disc with a focus on basic science of aging and degeneration, selecting the latest findings and discussions of the area, which influence future research and clinical thoughts.
\end{abstract}

Keywords: Intervertebral disc/anatomy \& histology; Extracellular matrix; Cytokines; Immunohistochemistry.

\section{RESUMO}

Atualmente ocorre um crescente interesse no estudo dos discos intervertebrais em virtude da perda da força de trabalho que a lombalgia e a cervicalgia trazem à sociedade. Esses trabalhos buscam delinear a diferença entre envelhecimento normal e degeneração discal, tentando entender qual fator seria determinante para a segunda condição. Assim, o campo da morfologia foi ampliado e o conhecimento sobre a estrutura dos discos intervertebrais hoje utiliza investigações no campo da biologia celular, molecular e da genética. Os resultados apontam que, independentemente da idade ou condição de enfermidade, o disco intervertebral sofre extenso e longo remodelamento de seus constituintes, os quais sofrem influências de diversos fatores: ambientais, solúveis e de crescimento das células e da matriz extracelular. Nesta revisão da literatura, descrevem-se as características biológicas do disco intervertebral cervical e lombar, com foco na ciência básica do envelhecimento e degeneração, selecionando as mais recentes descobertas e discussões da área, as quais influenciam futuras pesquisas e pensamentos clínicos.

Descritores: Disco intervertebral/anatomia \& histologia; Matriz extracelular; Citocinas; Imuno-histoquímica.

\section{RESUMEN}

Actualmente existe un creciente interés en el estudio de los discos intervertebrales debido a la pérdida de mano de obra que el dolor del cuello y lumbar aportan a la sociedad. Estas obras tratan de delimitar la diferencia entre el envejecimiento normal y la degeneración del disco, tratando de entender qué factor sería decisivo para la segunda condición. Así, el campo de la morfología se amplió y los conocimientos sobre la estructura de los discos intervertebrales utiliza actualmente la investigación en el campo de la biología celular y molecular, además de la genética. Los resultados indican que, independientemente de su edad o estado de la enfermedad, el disco intervertebral sufre una remodelación extensa y larga de sus componentes, que son influenciados por varios factores: el ambiente, solubles y de crecimiento celular y de la matriz extracelular. En esta revisión de la literatura se describen las características biológicas del disco intervertebral cervical y lumbar, con un enfoque en la ciencia básica del envejecimiento y la degeneración, seleccionando los últimos descubrimientos y discusiones del área, que influyen en la futura investigación y pensamientos clínicos.

Descriptores: Disco intervertebral/anatomía \& histología; Matriz extracelular; Citocinas; Inmunohistoquímica.

\section{INTRODUCTION}

Complaints related to the neck and lower back regions, associated with spinal pathologies, affect subjects from all kinds of backgrounds around the world, and are among the main factors of impaired health among workers. ${ }^{1-3}$ It is estimated that 70 to $80 \%$ of the adult population will experience a clinically relevant episode of lower back pain at some time in their lives, ${ }^{4}$ and two out of every three people will present with cervicalgia (neck pain) in this same period. ${ }^{1,5,6}$
Since the $19^{\text {th }}$ century, the morphology of the spine has been studied, seeking to establish connections between the alterations that occur in the spine, and their potential to become pain causing agents. ${ }^{7}$ In general, the initial studies were focused on the structure of the joint processes and intervertebral discs (IVDs) using morphological, histopathological and radiological observations.

It was only in the 1990s that, due to advances in the field of cell and molecular biology, ${ }^{8,9}$ more detailed evaluations involving the IVD

1. Universidade Federal do Espírito Santo, Department of Morphology, Vitória, ES, Brazil.

2. Rush University Medical Center, Department of Neurosurgery, Chicago, Illinois, United States of America.

3. Universidade de São Paulo, Department of Anatomy, São Paulo, SP, Brazil.

Study conducted at the Universidade Federal do Espírito Santo, Laboratório de Estudos em Morfologia Aplicada (LEMA - Laboratory for Applied Morphology Studies), Vitória, ES, Brazil.

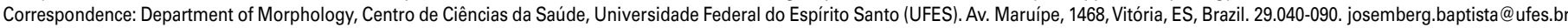


structure and its modifications became possible. Thus, the aim of this study is to review advances in the basic area, on abnormalities resulting from the process of aging and degeneration in IVDs.

\section{Intervertebral disc aging and degeneration}

The limit between disc aging and pathological abnormalities is absolutely indistinct, and has been recognized as such since the start of morphological studies on the intervertebral disc. ${ }^{10-12}$ In an attempt to clarify this limit, researchers have investigated the morphological characteristics of IVDs taken from symptomatic or asymptomatic patients of varying ages, in order to relate the severity of neck pain and lower back pain to the severity of morphologic lesions.

The classical series of studies by Conventry et al. ${ }^{10-12}$ collected the first ideas about the dynamic of changes to which IVDs are subject over a person's lifetime. The observations relative to morphology and age group include: the disappearance of the vascular channels originating from the endplate (EP), (Figure 1A) densification of the fibers that constitute the annulus fibrosus (AF), (Figure 1B) progressive loss of annulus-nucleus distinction (Figure $1 \mathrm{C}$ and $\mathrm{D}$ ), substitution of the original nuclear tissue by fibrocartilage, (Figure $1 \mathrm{E})$ the appearance of chondrocyte agglomerates in the deep part of the disc, cartilaginous hyalinization of the endplate, vascularization of the posterior portion of the annulus fibrosus, the appearance of fissures in the disc, and the extrusion (in a small quantity) of nuclear material through the endplate (Schmorl's node) ${ }^{11}$ (Figure $1 \mathrm{E}$ and $\mathrm{F}$ ). With regard the findings derived from abnormal or pathological conditions, as in degenerative disc disease, these include: the appearance of osteophytes, expansion and swelling of the nucleus pulposus (NP) (Figure 1C), anterior and posterior protrusions (with total or partial rupture of the annulus fibrosus fibers), the presence of Schmorl's nodes and NP calcifications (Figure 1E), and disc flattening $^{12}$ (Figure 1F). The criterion of these findings was the frequency with which they occur, ${ }^{12}$ although other authors also use severity and chronology. ${ }^{13}$ For the macroscopic analysis of these disc alterations, most studies ${ }^{14,15}$ use the Thompson scale, ${ }^{16}$ which attributes a grade of 1 to 5 , in increasing order of IVD alterations. (Figure 1)

Although considered the state of the art on the topic, it is still difficult to understand why an subjects of advanced age (e.g., 70 years old), with evident degeneration of the structural elements of the spine, does not manifest symptoms, while another person half this age, with better structural characteristics, presents with neck and lower back pain. 7,17,18 That said, it is unfeasible to point out a state of normality in the IVD, which instigates detailed research on the topic and has already revealed a considerable number of molecules involved in IVD aging and degeneration.

\section{Alterations in the extracellular matrix (ECM) of the intervertebral disc}

Briefly, alterations in the ECM occur through modification in the synthesis of type $\mathrm{II}$ collagen $(\mathrm{Col})^{19}$ to type ${ }^{1},{ }^{14}$ and reduction of aggrecan synthesis ${ }^{20}$ in the NP. This process can extend to and affect the annulus fibrosus, consequently reducing the intervertebral space. Similar changes occur in the EP, and may result in microfractures. ${ }^{21}$ Accordingly, the biomechanical balance existing beween the forces of the NP, AF and EP is lost, resulting in reduced tension of collagen in the AF, alteration of those resulting from the force vectors on the spine, and impacts caused by load during motion; which can lead to microtraumas and pain. ${ }^{19,22}$

In the initial stage of degeneration, collagen synthesis, in general, increases, with a clear increase in type II Col in the NP, presumably indicating the presence of a repair mechanism. ${ }^{23}$ With the progress of degeneration, the synthesis pattern changes and more type II Col is synthesized on the surface of the AF, forming strong collagen fibrils; nevertheless, type I Col is synthesized in the deep region of the AF and NP of these discs. Moreover, type X Col was associated with chondrocyte agglomerates and the formation of tears in degenerated IVDs, which means abnormal cell activity. ${ }^{24}$

The synthesis of proteoglycans (PGs) also changes with a decline in the production of aggrecan and an increase in the production of versican, biglycan and decorin; the amount of fibronectin also increases, along with a decrease in glycosaminoglycans (GAGs), especially the modification of chondroitin sulfate to keratan sulfate. All these changes result in less IVD hydration and are a result of existing disorders in the cell biology of the AF, NP and EP cells. 7,19,22,25-28

This remodeling of the ECM results from changes in the balance between synthesis and degradation of each subjects component of this matrix. The protagonists of this process are the matrix metalloproteinases (MMPs); enzymes that can collectively break down every type of ECM protein. ${ }^{19}$ There are also ADAMTS (a desintegrin and metalloproteinase with thrombospondin), which play a role similar to that of the MMPs, although more powerful in the break down of ECM. ${ }^{29}$ Both families have the same endogenous inhibitors, called TIMPs (tissue inhibitor matrix metalloproteinase), which act synergically in the remodeling of the ECM, whether the need is of a homeostatic or disease-related nature ${ }^{30}$ (Table 1).

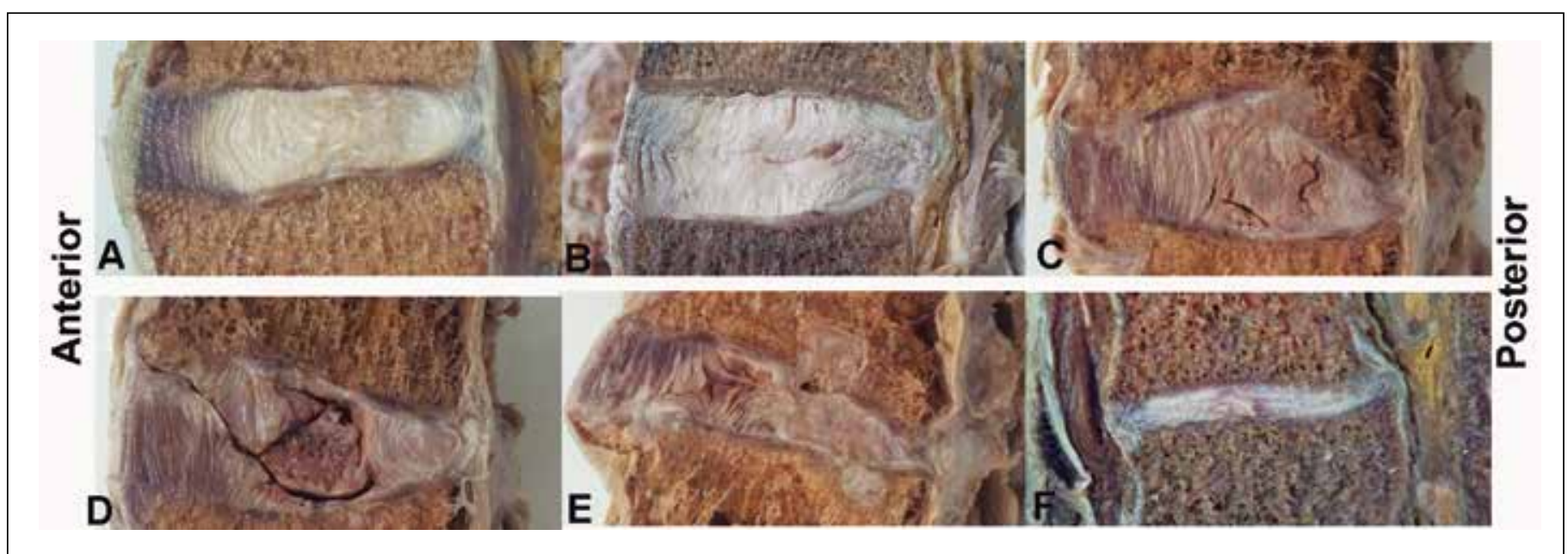

Figure 1. Lumbar intervertebral discs fixed in $4 \%$ formalin in sagittal section: Note the different macroscopic appearances found in the aging and degeneration process, evaluated according to Thompson's macroscopic degeneration scale ${ }^{16}$. (A) Thompson I: NP of gelatinous appearance and AF with organized lamellae; (B) Thompson II: NP with whitened fibrous tissue and mucinous material between the lamellae of the AF, note small fissure in the NP; (C) Thompson III: Loss of AF/NP distinction, focal defects in the VP, see dehydration of NP and longitudinal and vertical fissure; (D) Thompson IV: Fissures in the NP and parallel to the VP, with presence of focal sclerosis at this point; (E) Thompson V: Diffuse sclerosis and Schmorl's nodes; (F) Thompson 5: total sclerosis and flattening of the disc. Specimens from the collection of the Human Anatomy laboratory of UFES. 
Table 1. Main molecules involved in disc aging and degeneration.

\begin{tabular}{|c|c|c|c|}
\hline Classification & Molecule & Function & General repercussions on old age and infirmity \\
\hline \multirow{7}{*}{$\begin{array}{l}\text { Catabolic/ } \\
\text { Remodelers of } \\
\text { the ECM }\end{array}$} & MMP-1 (collagenase-1) & Degradation of collagens I, II, III and gelatin & \multirow{5}{*}{$\uparrow \uparrow \uparrow$ act in the remodeling of the ECM } \\
\hline & MMP-3 (stromelysin-1) & $\begin{array}{l}\text { Degradation of collagens II, III, IV, V, X, elastin, } \\
\text { fibronectin, laminin and activation of other MMPs }\end{array}$ & \\
\hline & MMP-13 (collagenase-3) & Degradation of collagens I, II, III, IV, IX, X and gelatin & \\
\hline & ADAMTS-4 (aggrecanase-1) & Degradation of aggrecan & \\
\hline & ADAMTS-5 (aggrecanase-2) & Most powerful degrader of aggrecan & \\
\hline & TIMP-1 & Endogenous inhibitor of MMPs -1 and -3 & \multirow{2}{*}{$\begin{array}{c}\text { Besides acting in the remodeling of the ECM, the } \\
\text { imbalance between MMPs/ADAMTS and TIMPs } \\
\text { generates degradation of the ECM }\end{array}$} \\
\hline & TIMP-3 & Endogenous inhibitor of ADAMTS- 4 and -5 & \\
\hline \multirow{3}{*}{$\begin{array}{l}\text { Catabolic/ } \\
\text { Cytokines }\end{array}$} & $\mathrm{IL}-1 \beta$ & $\begin{array}{l}\text { Regulates the immune and inflammatory response. } \\
\text { Activates T lymphocyte, B lymphocyte, and NK cell. }\end{array}$ & \multirow{2}{*}{$\begin{array}{l}\uparrow \uparrow \uparrow \text { particularly in degeneration, being responsible } \\
\text { for the catabolic metabolism }\end{array}$} \\
\hline & TNF- $\alpha$ & $\begin{array}{l}\text { Regulates the immune and inflammatory response. } \\
\text { Acts in apoptosis. }\end{array}$ & \\
\hline & IL -1Ra (receptor antagonist) & Natural competitor to IL -1 receptors & $\begin{array}{c}\downarrow \downarrow \downarrow \text { especially in the presence of the } \\
\text { degenerative process }\end{array}$ \\
\hline \multirow{3}{*}{ Growth factors } & VEGF & Acts in the development of endothelial cells & $\uparrow \uparrow \uparrow$ in response to a possible repair mechanism \\
\hline & NGF- $\beta$ & $\begin{array}{c}\text { Acts in axonogenesis, in the differentiation of sensory } \\
\text { neurons and in neuron functions mediated by } \\
\text { pain and inflammation. }\end{array}$ & \multirow{2}{*}{$\begin{array}{c}\text { Stimulate axon growth. Are the possible origin of } \\
\text { discogenic pain or can be considered a structure } \\
\text { protection factor }\end{array}$} \\
\hline & BDNF & $\begin{array}{c}\text { Acts in axonogenesis, maintenance of subpopulations } \\
\text { and neuroplasticity. }\end{array}$ & \\
\hline
\end{tabular}

The ECM remodelers most frequently studied in disc aging and degeneration are: MMP-1, -3 , and -13 , which degrade type I, II, III, IV, V and X collagens (Figure 2); ADAMTS-4 and -5, which break down aggrecan and other PGs; and TIMP-1 inhibitors, for the abovementioned MMPs, as well as TIMP-3 for ADAMTS. ${ }^{31-37}$ It is clear that the imbalance between the expression of MMPS/ADAMTS in the disc tissue and those of TIMPs results in a loss of structural integrity, decreased IVD hydration, diminished ability to resist load, and other phenotypic characteristics of the aged/degenerated IVD, already described here. $7,19,22,25-28$ Microscopically speaking, IVD chondrocytes are usually identified as expressing these molecules close to a tissue lesion such as tears and fissures 20,32,33 (Figure 2A). Additionally, soluble factors such as several cytokines (IL-1 $\beta$, interleukin-1 and TNF- $\alpha$, tumor necrosis factor), growth factors (VEGF, vascular endothelial growth factor) and neurotrophins (NGF- $\beta$, nerve growth factor, and BDNF, brain-derived neurotrophic factor) can modulate the action of the MMPs, ADAMTS and TIMPs. (Table 1)

\section{Action of proinflammatory cytokines on the intervertebral disc}

The specific changes of the ECM of IVDs, the biomechanical events that influence its biology, loss of vascularization, and the consequent change in availability of nutrients and growth factors for its cells ${ }^{38,39}$ favor alterations of the normal functions performed by this anatomical structure. This process also results in the release of proinflammatory cytokines capable of influencing local cell activity. ${ }^{40}$

IVD cells are able to synthesize various proinflammatory cytokines, including: bFGF (basic fibroblast growth factor), phospholipase A2, GM-CSF (granulocyte macrophage colony stimulation factor), IGF-1 (insulin-like growth factor), interleukin-1 $\beta$, interleukin-6, interleukin-8, interleukin-10, PGE2 (prostaglandin E2), TGF- $\beta$ (transforming growth factor) and TNF- $\alpha^{40}$ (Figure 2B). IL-1 $\beta$ and TNF- $\alpha$ are the proinflammatory mediators with the largest amount of accumulated evidence in studies on disc degeneration, with a modulator effect in the family of MMPs. ${ }^{25}$

Not only is IL-1 $\beta$ able to induce the characteristic changes in the ECM of degenerating discs, ${ }^{20,32,35,36,41}$ its expression also increases during this process, without an corresponding increase in its natural inhibitor, IL-1RA (interleukin 1 Receptor antagonist). ${ }^{41}$ There is evidence that knockout mice for IL-1RA exhibit loss of PGs and of the normal collagen structure of IVDs, as well as an increase in the expression of MMP-3, MMP-7. ${ }^{42}$ This leads us to believe that $\mathrm{IL}-1$ is a key molecule in the disc degeneration process. Likewise, TNF- $\alpha$ has been linked to disc modifications resulting from age and degeneration, ${ }^{43-47}$ although, on the other hand, this cytokine has been pointed as the most catabolic and anti-anabolic in disc tissue events. ${ }^{48,49}$ Moreover, both cytokines have been postulated as activators of two potent aggrecanases, ADAMTS-4 and -5, through protein co-expression pathways. ${ }^{46}$ (Table 1 )

Although the means (intrinsic or extrinsic to the disc environment) that lead to deregulation in the production of IL-1 $\beta$ and TNF- $\alpha$ have not yet been elucidated, these are known to be related to the increase of matrix degrading enzymes, abnormal synthesis of aggrecan and type II collagen, besides its substitution by type I, angiogenesis, axonogenesis and apoptosis of IVD cells. ${ }^{19,50-53}$

\section{Angiogenesis in the intervertebral disc}

It is believed that increased load on the vertebral structures, and the need for nutrition, growth and regeneration of tissues, are the reasons for vascular growth in the IVD. 7,26,54

VEGF is produced by the IVD cells (Figure $2 \mathrm{C}$ ) and is able to activate MMP-3, $-9,-12$ and $-13,{ }^{55}$ evidencing the role of this glycoprotein in disc remodeling (Table 1 ). Its expression is also related to that of $\mathrm{IL}-1 \beta$ and TNF- $\alpha$ in the NP, especially the first, and that together, there is expression of PECAM-1 (platelet endothelial cell adhesion molecule), a molecule present only in endothelial cells. This ratifies neoangiogenesis in the disc tissue. ${ }^{56}$ Thus it is currently believed that the presence of VEGF in IVDs originates from the inflammatory chain due to the metabolic requirement of the region. ${ }^{56,57}$

\section{Axonogenesis in the intervertebral disc and discogenic pain}

In association with angiogenesis, the detection of nerve fibers in deeper regions than the peripheral one-third of the IVD has been documented in samples from symptomatic subjects, and pointed as responsible for discogenic pain. ${ }^{25,58}$ From a macroscopic point of view, the nerve pathways involved in this process are: the meningeal branches and grey rami communicans, ${ }^{7}$ present in the peripheral one-third of the AF and that through axogenesis, extend deeper into the disc tissue, ${ }^{58,59}$ and the dorsal ganglion of the spinal nerve, which has nociceptive capacity in relation to peptides involved in pain modulation. ${ }^{8}$ It is assumed that the IVD cells lose the anti-angiogenic and 
anti-axonogenic factors in the degenerative process. ${ }^{25,60,61}$ Thus, two neurotrophins have revealed a close relationship with this process: NGF- $\beta$ (nerve growth factor) (Figure 2D) and BDNF (brain-derived neurotrophic factor) (Table 1). However, BDNF is the neurotrophic most closely related to nociceptive sensitivity in the IVD. 62

Both have been detected near the neoformed vessels that enter the IVD through the EP, 56,63 and modulate interaction between NP cells (Figure 2D) and the dorsal root ganglion. Thus, it is possible to control nerve growth into the interior of the intervertebral disc. ${ }^{64}$ Furthermore, these molecules are capable of inducing co-expression of nociceptive peptides in the disc tissue, and stimulating discogenic pain. ${ }^{64}$

The results of research on the interaction between the axonogenesis process, angiogenesis and remodeling of the disc extracellular matrix ${ }^{65-68}$ make it clear that the constituents of the IVD ECM act as preventive agents of this process, as do the molecules of the collapsins group (semaphorin). ${ }^{60,69}$ Other evidence has been found, such as the modulation of the expression of these neurotrophins through $\mathrm{IL}-1 \beta,{ }^{49,70,71}$ the proportionality between the severity of disc degeneration and the amount of cytokines detected, ${ }^{49}$ and the association between the reduction of semaphorins and greater expression of PECAM- 1 in the tissue. ${ }^{60}$

One of the most interesting data currently verified in the litera-

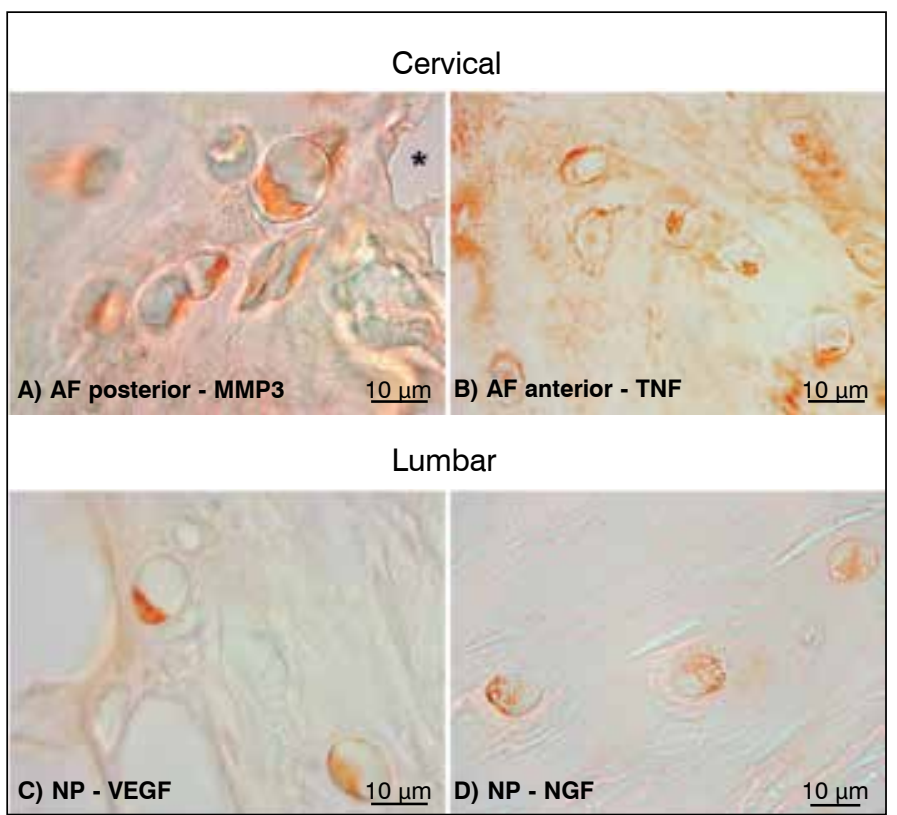

Figure 2. Assays with immunohistochemical technique in IVDs extracted from individuals presumed asymptomatic. A-C) Elderly IVD (>65 years); D) young IVD (34 years). See in (A) chondrocytes of varied morphology expressing MMP-3 close to a tear or fissure in the tissue; in (B) detection of TNF- $\alpha$ in the ECM and in the chondrocytes; in (C) expression of VEGF in chondrocytes from the deep region of the NP and, in (D), note especially the immunodetection of NGF- $\beta$ in the NP of a young individual.

\section{REFERENCES}

1. Côté P, van der Velde G, Cassidy JD, Carroll LJ, Hogg-Johnson S, Holm LW, et al. The burden and determinants of neck pain in workers: results of the Bone and Joint Decade 2000-2010 Task Force on Neck Pain and Its Associated Disorders. Spine (Phila Pa 1976). 2008;33(4 Suppl):S60-74

2. Hogg-Johnson S, van der Velde G, Carroll LJ, Holm LW, Cassidy JD, Guzman J, et al. The burden and determinants of neck pain in the general population: results of the Bone and Joint Decade 2000-2010 Task Force on Neck Pain and Its Associated Disorders. Spine (Phila Pa 1976). 2008 Feb 15;33(4 Suppl):S39-51.

3. Martin BI, Deyo RA, Mirza SK, Turner JA, Comstock BA, Hollingworth W, et al. Expenditures and health status among adults with back and neck problems. JAMA. 2008;299(6):656-64.

4. Rubin DI. Epidemiology and risk factors for spine pain. Neurol Clin. 2007;25(2):353-71.

5. Fejer R, Kyvik KO, Hartvigsen J. The prevalence of neck pain in the world population: a systematic critical review of the literature. Eur Spine J. 2006:15(6):834-48.

6. Côté P, van der Velde G, Cassidy JD, Carroll LJ, Hogg-Johnson S, Holm LW, et al. The burden and determinants of neck pain in workers: results of the Bone and Joint Decade ture was the ability of the NP cells to produce mediators capable of inhibiting or stimulating (Figure 2D) nerve growth to this region of the IVD, proving the theory that there are anti-angiogenic and antiaxonogenic agents in the disc tissue, and that these cells have the ability to modulate nerve growth into the tissue. ${ }^{61,68}$

\section{Genetics and disc degeneration}

Few genetic associations have been made in the field of disc degeneration. Most of these studies use the phenotype-gene-candidate association. However, that model is ideally used for diseases caused by a single gene with Mendelian inheritance pattern. Therefore, as disc degeneration is a polygenic condition, with important environmental influences, variation according to ethnicity, and phenotypic characteristics that are not well standardized in the literature, the statistical power of these studies is greatly reduced. ${ }^{72-75}$ The alternative approach would be the genome-wide association study; However this model pinpoints genes in a very broad way, frequently involving those whose localization and function are not known. ${ }^{74,76}$

The most widely studied genes are those that codify Col IX (COL9A1 gene) ${ }^{77}$ (COL9A2 gene), ${ }^{73,75} \mathrm{Col}$ I (COL1A1 gene), ${ }^{78}$ MMP- $3,{ }^{79}$ and the VDR gene (vitamin D receptor). ${ }^{80}$ The most important associations were achieved in the study of mutations of the VDR gene (vitamin D receptor). Certain alleles for Taq1 polymorphism of the VDR gene are associated with disc degeneration. ${ }^{74,80}$ On the other hand, it is impossible to imagine a direct role for the polymorphisms of this gene in disc degeneration; these VDR polymorphisms probably represent only a marker for mutations of other genes, as there is a structural proximity both for the COL2A1 gene and for IGF-1. These are known to be involved in the composition and degenerative process of the intervertebral disc, and it is to be expected that future genetic studies will shed light on how these genes relate to the VDR polymorphisms identified so far. $^{74}$

\section{FINAL CONSIDERATIONS}

Despite the volume of knowledge achieved on IVD in the last three decades, the distinction between disc aging and degenerative disc disease still remains unclear, particularly due to its multifactorial origin. Thus, it is to be expected that subjects of different ages may exhibit morphological alterations in the IVDs, without necessarily suffering from a pathological condition. Although surgical treatment has improved in terms of safety, the procedure has changed very little in the last fifty years; on the other hand, many studies already see modulation of the inflammatory/enzymatic process as a means of treatment, where the first effective treatments for degenerative disc disease are expected to be achieved, by intervening directly in the disease physiopathology. Moreover, more modern therapies, using stem cells and bioengineering, are advancing rapidly, even if clinical and surgical applications are still a long way off.

All authors declare no potential conflict of interest concerning this article.
2000-2010 Task Force on Neck Pain and Its Associated Disorders. J Manipulative Physiol Ther. 2009;32(2 Suppl):S70-86.

7. Roh JS, Teng AL, Yoo JU, Davis J, Furey C, Bohlman HH. Degenerative disorders of the lumbar and cervical spine. Orthop Clin North Am. 2005;36(3):255-62.

8. Grönblad M, Weinstein JN, Santavirta S. Immunohistochemical observations on spinal tissue innervation. A review of hypothetical mechanisms of back pain. Acta Orthop Scand. 1991:62(6):614-22

9. McCarthy PW, Carruthers B, Martin D, Petts P. Immunohistochemical demonstration of sensory nerve fibers and endings in lumbar intervertebral discs of the rat. Spine (Phila Pa 1976). 1991;16(6):653-5.

10. Coventry MB, Ghormley RK, Kernohan JW. The intervertebral disc: its microscopic anatomy and pathology. Part I: Anatomy, development and pathology. J Bone Joint Surg Am. 1945;27:105-12.

11. Coventry MB, Ghormley RK, Kernohan JW. The intervertebral disc: its microscopic anatomy and pathology. Part II: Changes in the intervertebral disc concomitant with age. J Bone Joint Surg Am. 1945;27:233-47. 
12. Coventry MB, Ghormley RK, Kernohan JW. The intervertebral disc: its microscopic anatomy and pathology. Part III: Pathological changes in the intervertebral. J Bone Joint Surg Am. 1945;27:460-74.

13. Harris RI, MacNab I. Structural changes in the lumbar intervertebral discs; their relationship to low back pain and sciatica. J Bone Joint Surg Br. 1954:36(2):304-22.

14. Boos N, Weissbach S, Rohrbach H, Weiler C, Spratt KF, Nerlich AG. Classification of age-related changes in lumbar intervertebral discs: 2002 Volvo Award in basic science. Spine (Phila Pa 1976). 2002;27(23):2631-44

15. Weiler C, Schietzsch M, Kirchner T, Nerlich AG, Boos N, Wuertz K. Age-related changes in human cervical, thoracal and lumbar intervertebral disc exhibit a strong intra-individual correlation. Eur Spine J. 2012;21(Suppl 6):S810-8.

16. Thompson JP, Pearce RH, Schechter MT, Adams ME, Tsang IK, Bishop PB. Preliminary evaluation of a scheme for grading the gross morphology of the human intervertebral disc. Spine (Phila Pa 1976). 1990:15(5):411-5.

17. Chan WC, Sze KL, Samartzis D, Leung VY, Chan D. Structure and biology of the intervertebral disk in health and disease. Orthop Clin North Am. 2011;42(4):447-64

18. Matsumoto M, Okada E, Toyama Y, Fujiwara H, Momoshima S, Takahata T. Tandem age -related lumbar and cervical intervertebral disc changes in asymptomatic subjects. Eur Spine J. 2013:22(4):708-13.

19. Le Maitre CL, Pockert A, Buttle DJ, Freemont AJ, Hoyland JA. Matrix synthesis and degradation in human intervertebral disc degeneration. Biochem Soc Trans. 2007;35(Pt 4):652-655

20. Le Maitre CL, Freemont AJ, Hoyland JA. Localization of degradative enzymes and their inhibitors in the degenerate human intervertebral disc. J Pathol. 2004:204(1):47-54.

21. Adams MA, Pollintine P, Tobias JH, Wakley GK, Dolan P. Intervertebral disc degeneration can predispose to anterior vertebral fractures in the thoracolumbar spine. J Bone Miner Res. 2006;21(9):1409-1416.

22. 2Adams MA, Roughley PJ. What is intervertebral disc degeneration, and what causes it? Spine (Phila Pa 1976). 2006;31(18):2151-2161.

23. Takaishi H, Nemoto O, Shiota M, Kikuchi T, Yamada H, Yamagishi M, et al. Type-Il collagen gene expression is transiently upregulated in experimentally induced degeneration of rabbit intervertebral disc. J Orthop Res. 1997;15(4):528-38.

24. Boos N, Nerlich AG, Wiest I, von der Mark K, Aebi M. Immunolocalization of type X collagen in human lumbar intervertebral discs during ageing and degeneration. Histochem. Cell Biol. 1997;108(6):471-480

25. Freemont AJ. The cellular pathobiology of the degenerate intervertebral disc and discogenic back pain. Rheumatology (Oxford). 2009:48(1):5-10.

26. Freemont AJ, Watkins $A$, Le Maitre $C$, Jeziorska $M$, Hoyland JA. Current understanding of cellular and molecular events in intervertebral disc degeneration: implications for therapy. J Pathol. 2002;196(4):374-9.

27. Adams MA, McNally DS, Dolan P. "stress" Distributions Inside Intervertebral Discs the Effects of Age and Degeneration. J Bone Joint Surg Br. 1996:78(6):965-72.

28. Zhao CQ, Wang LM, Jiang LS, Dai LY. The cell biology of intervertebral disc aging and degeneration. Ageing Res Rev. 2007;6(3):247-61.

29. Jones GC, Riley GP. ADAMTS proteinases: a multi-domain, multi-functional family with roles in extracellular matrix turnover and arthritis. Arthritis Res Ther. 2005:7(4):160-9.

30. Singh K, Masuda K, Thonar EJ, An HS, Cs-Szabo G. Age-related changes in the extracellular matrix of nucleus pulposus and anulus fibrosus of human intervertebral disc. Spine (Phila Pa 1976). 2009;34(1):10-6

31. Nishida T. Kinetics of tissue and serum matrix metalloproteinase-3 and tissue inhibitor of metalloproteinases- 1 in intervertebral disc degeneration and disc herniation. Kurume Med J. 1999:46(1):39-50.

32. Weiler C, Nerlich AG, Zipperer J, Bachmeier BE, Boos N. 2002 SSE Award Competition in Basic Science: expression of major matrix metalloproteinases is associated with intervertebral disc degradation and resorption. Eur Spine J. 2002;11(4):308-20.

33. Bachmeier BE, Nerlich A, Mittermaier N, Weiler C, Lumenta C, Wuertz K, et al. Matrix metalloproteinase expression levels suggest distinct enzyme roles during lumbar disc herniation and degeneration. Eur Spine J. 2009;18(11):1573-1586.

34. Zigouris A, Batistatou A, Alexiou GA, Pachatouridis D, Mihos E, Drosos D, et al. Correlation of matrix metalloproteinases-1 and -3 with patient age and grade of lumbar disc herniation. J Neurosurg Spine. 2011:14(2):268-72.

35. Sive JI, Baird P, Jeziorsk M, Watkins A, Hoyland JA, Freemont AJ. Expression of chondrocyte markers by cells of normal and degenerate intervertebral discs. Mol Pathol. 2002;55(2):91-7.

36. Roberts S, Caterson B, Menage J, Evans EH, Jaffray DC, Eisenstein SM. Matrix metalloproteinases and aggrecanase: their role in disorders of the human intervertebral disc. Spine (Phila Pa 1976). 2000;25(23):3005-13.

37. Roberts S, Menage J, Duance V, Wotton S, Ayad S. 1991 Volvo Award in basic sciences Collagen types around the cells of the intervertebral disc and cartilage end plate: an immunolocalization study. Spine (Phila Pa 1976). 1991;16(9):1030-8.

38. Gruber HE, Hanley EN Jr. Analysis of aging and degeneration of the human intervertebra disc. Comparison of surgical specimens with normal controls. Spine (Phila Pa 1976). 1998;23(7):751-7.

39. Maroudas A, Stockwell RA, Nachemson A, Urban J. Factors involved in the nutrition of the human lumbar intervertebral disc: cellularity and diffusion of glucose in vitro. J Anat. 1975;120(Pt 1):113-30.

40. Podichetty VK. The aging spine: the role of inflammatory mediators in intervertebral disc degeneration. Cell Mol Biol (Noisy-le-grand). 2007;53(5):4-18.

41. Le Maitre CL, Freemont AJ, Hoyland JA. The role of interleukin-1 in the pathogenesis of human intervertebral disc degeneration. Arthritis Res Ther. 2005:7(4):R732-45

42. Phillips KL, Jordan-Mahy N, Nicklin MJ, Le Maitre CL. Interleukin-1 receptor antagonist deficient mice provide insights into pathogenesis of human intervertebral disc degeneration. Ann Rheum Dis. $2013 ; 72(11): 1860-7$.

43. Weiler C, Nerlich AG, Bachmeier BE, Boos N. Expression and distribution of tumor necrosis factor alpha in human lumbar intervertebral discs: a study in surgical specimen and autopsy controls. Spine (Phila Pa 1976). 2005;30(1):44-53.

44. Igarashi T, Kikuchi S, Shubayev V, Myers RR. 2000 Volvo Award winner in basic science studies: Exogenous tumor necrosis factor-alpha mimics nucleus pulposus-induced neuropathology. Molecular, histologic, and behavioral comparisons in rats. Spine (Phila Pa 1976). 2000;25(23):2975-80.

45. Wang J, Markova D, Anderson DG, Zheng Z, Shapiro IM, Risbud MV. TNF- $\alpha$ and IL-1 $\beta$ promote a disintegrin-like and metalloprotease with thrombospondin type I motif-5- -mediated aggrecan degradation through syndecan-4 in intervertebral disc. J Biol Chem. 2011;286(46):39738-49

46. Wang J, Tian Y, Phillips KL, Chiverton N, Haddock G, Bunning RA, et al. Tumor necrosis factor $\alpha$ - and interleukin-1 $\beta$-dependent induction of CCL3 expression by nucleus pulposus cells promotes macrophage migration through CCR1. Arthritis Rheum. 2013;65(3):832-42.

47. Hoyland JA, Le Maitre C, Freemont AJ. Investigation of the role of IL-1 and TNF in matrix degradation in the intervertebral disc. Rheumatology (Oxford). 2008:47(6):809-14.

48. Le Maitre CL, Hoyland JA, Freemont AJ. Catabolic cytokine expression in degenerate and herniated human intervertebral discs: IL-1 beta and TNFalpha expression profile. Arthritis Res Ther. 2007;9(4):R77.

49. Purmessur D, Walter BA, Roughley PJ, Laudier DM, Hecht AC, latridis J. A role for TNF $\alpha$ in intervertebral disc degeneration: a non-recoverable catabolic shift. Biochem Biophys Res Commun. 2013;433(1):151-6.

50. Goldring SR, Goldring MB. The role of cytokines in cartilage matrix degeneration in osteoarthritis. Clin Orthop Relat Res. 2004;(427 Suppl):S27-36.

51. Maruotti N, Cantatore FP, Crivellato E, Vacca A, Ribatti D. Angiogenesis in rheumatoid arthritis. Histol Histopathol. 2006;21(5):557-66.

52. Brisby H. Pathology and possible mechanisms of nervous system response to disc degeneration. J Bone Joint Surg Am. 2006;88 Suppl 2:68-71.

53. Zhao CQ, Liu D, Li H, Jiang LS, Dai LY. Interleukin-1beta enhances the effect of serum deprivation on rat annular cell apoptosis. Apoptosis. 2007:12(12):2155-61.

54. Vora AJ, Doerr KD, Wolfer LR. Functional anatomy and pathophysiology of axial low back pain: disc, posterior elements, sacroiliac joint, and associated pain generators. Phys Med Rehabil Clin N Am. 2010;21(4):679-709.

55. Lijnen HR. Plasmin and matrix metalloproteinases in vascular remodeling. Thromb Haemost. 2001;86(1):324-33

56. Lee JM, Song JY, Baek M, Jung HY, Kang H, Han IB, et al. Interleukin-1 $\beta$ induces angiogenesis and innervation in human intervertebral disc degeneration. $\mathrm{J}$ Orthop Res. 2011:29(2):265-9.

57. Koike Y, Uzuki M, Kokubun S, Sawai T. Angiogenesis and inflammatory cell infiltration in lumbar disc herniation. Spine (Phila Pa 1976). 2003;28(17):1928-33.

58. Freemont AJ, Peacock TE, Goupille P, Hoyland JA, O'Brien J, Jayson MI. Nerve ingrowth into diseased intervertebral disc in chronic back pain. Lancet. 1997:350(9072):178-81.

59. Coppes MH, Marani E, Thomeer RT, Groen GJ. Innervation of "painful" lumbar discs Spine (Phila Pa 1976). 1997;22(20):2342-9.

60. Tolofari SK, Richardson SM, Freemont AJ, Hoyland JA. Expression of semaphorin 3A and its receptors in the human intervertebral disc: potential role in regulating neural ingrowth in the degenerate intervertebral disc. Arthritis Res Ther. 2010;12(1):R1.

61. Richardson SM, Purmessur D, Baird P, Probyn B, Freemont AJ, Hoyland JA. Degenerate human nucleus pulposus cells promote neurite outgrowth in neural cells. PLoS One. 2012;7(10):e47735

62. Gruber HE, Ingram JA, Hoelscher G, Zinchenko N, Norton HJ, Hanley EN Jr. Brain-derived neurotrophic factor and its receptor in the human and the sand rat intervertebral disc. Arthritis Res Ther. 2008;10(4):R82.

63. Freemont AJ, Watkins A, Le Maitre C, Baird P, Jeziorska M, Knight MT, et al. Nerve growth factor expression and innervation of the painful intervertebral disc. J Pathol. 2002;197(3):286-92

64. Yamauchi K, Inoue G, Koshi T, Yamashita M, Ito T, Suzuki M, et al. Nerve growth factor of cultured medium extracted from human degenerative nucleus pulposus promotes sensory nerve growth and induces substance $p$ in vitro. Spine (Phila Pa 1976). 2009;34(21):2263-9

65. Melrose J, Roberts S, Smith S, Menage J, Ghosh P. Increased nerve and blood vessel ingrowth associated with proteoglycan depletion in an ovine anular lesion model of experimental disc degeneration. Spine (Phila Pa 1976). 2002:27(12):1278-85.

66. Johnson WE, Caterson B, Eisenstein SM, Hynds DL, Snow DM, Roberts S. Human intervertebral disc aggrecan inhibits nerve growth in vitro. Arthritis Rheum. 2002;46(10):2658-64

67. Johnson WE, Caterson B, Eisenstein SM, Roberts S. Human intervertebral disc aggrecan inhibits endothelial cell adhesion and cell migration in vitro. Spine (Phila Pa 1976). 2005;30(10):1139-47.

68. Johnson WE, Sivan S, Wright KT, Eisenstein SM, Maroudas A, Roberts S. Human intervertebral disc cells promote nerve growth over substrata of human intervertebral disc aggrecan. Spine (Phila Pa 1976). 2006:31(11):1187-93.

69. de Wit J, Verhaagen J. Role of semaphorins in the adult nervous system. Prog Neurobiol. 2003;71(2-3):249-67.

70. Abe Y, Akeda K, An HS, AokiY, Pichika R, Muehleman C, et al. Proinflammatory cytokines stimulate the expression of nerve growth factor by human intervertebral disc cells. Spine (Phila Pa 1976). 2007:32(6):635-42.

71. Olmarker K. Neovascularization and neoinnervation of subcutaneously placed nucleus pulposus and the inhibitory effects of certain drugs. Spine (Phila Pa 1976). 2005;30(13):1501-4

72. Chan D, Song Y, Sham P, Cheung KM. Genetics of disc degeneration. Eur Spine J. 2006:15(Suppl 3):S317-25

73. Annunen S, Paassilta P, Lohiniva J, Perälä M, Pihlajamaa T, Karppinen J, et al. An allele of COL9A2 associated with intervertebral disc disease. Science. 1999;285(5426):409-12.

74. Kalichman L, Hunter DJ. The genetics of intervertebral disc degeneration. Associated genes. Joint Bone Spine. 2008:75(4):388-96.

75. Seki S, KawaguchiY, Mori M, Mio F, Chiba K, MikamiY, et al. Association study of COL9A2 with lumbar disc disease in the Japanese population. J Hum Genet. 2006;51(12):1063-7.

76. Gruber HE, Hoelscher GL, Hanley EN Jr. Annulus cells from more degenerated human discs show modified gene expression in 3D culture compared with expression in cells from healthier discs. Spine J. 2010;10(8):721-7.

77. Boyd LM, Richardson WJ, Allen KD, Flahiff C, Jing L, LiY, et al. Early-onset degeneration of the intervertebral disc and vertebral end plate in mice deficient in type IX collagen. Arthritis Rheum. 2008:58(1):164-71.

78. Tilkeridis C, Bei T, Garantziotis S, Stratakis CA. Association of a COL1A1 polymorphism with lumbar disc disease in young military recruits. J Med Genet. 2005;42(7):e44.

79. Takahashi M, Haro H, WakabayashiY, Kawa-uchi T, Komori H, Shinomiya K. The association of degeneration of the intervertebral disc with $5 \mathrm{a} / 6 \mathrm{a}$ polymorphism in the promoter of the human matrix metalloproteinase-3 gene. J Bone Joint Surg Br. 2001;83(4):491-5.

80. Jones G, White C, Sambrook P, Eisman J. Allelic variation in the vitamin D receptor, lifestyle factors and lumbar spinal degenerative disease. Ann Rheum Dis. 1998;57(2):94-9. 